\title{
Assessment of Different Dust Pollutants Effect on Total Chlorophyll Content, Transpiration Rate and Yield of Blackgram (Phaseolus mungo L.)
}

\author{
P. Hareesh Babu" ${ }^{*}$ K.L. Narasimha Rao, K. Jayalalitha and Mohammed Anwar Ali \\ Department of Crop Physiology, Agricultural College Bapatla, \\ ANGRAU (A.P)-522 101, India
}

A B S T R A C T

\begin{abstract}
Keywords
Blackgram (Phaseolus mungo L.), Dust

pollution, Cement, Stone

crusher, Lime dust,

Transpiration rate, Total

chlorophyll content and yield
\end{abstract}

Article Info

Accepted:

23 March 2018

Available Online:

10 April 2018
An experiment was conducted at Agricultural college farm, Bapatla, Andhra Pradesh to study the 'Assessment of effect of different dust (cement, stone crusher, and lime) pollutants at various levels on total chlorophyll content, transpiration rate and yield of blackgram (Phaseolus mungo L.). The experiment revealed that with an increase in applied dust leads to the decrease in total chlorophyll content and transpiration rate in plants that further engender lesser yields compared to the control. Among these dusts Cement dust @ $150 \mathrm{gm}^{-2}$ (T10), Cement dust @ $100 \mathrm{gm}^{-2}$ (T9) and Stone crusher dust @ $150 \mathrm{gm}^{-2}$ decreased the total chlorophyll content in the leaves of blackgram respectively, compared to control. Decrease in transpiration rate was observed with cement dust $150 \mathrm{gm}^{-2}$, over control and gradual decrease of per cent number of pods per plant, decrease in number of seeds per pod over control. With respect to 100 seed weight, cement dust @ $150 \mathrm{gm}^{-2}$ (T10) and cement dust@100 gm gm $^{-2}$ (T9) recorded 16.48 and 14.07 per cent decrease, respectively, over control. Cement dust @ $150 \mathrm{gm}^{-2}$ (T10) showed the highest reduction of seed yield $\mathrm{ha}^{-1}$ and harvest index compared to control.

\section{Introduction}

India is the largest producer and consumer of pulses in the world. Pulses are major sources of proteins among the vegetarian diet in India, and complement the staple cereals in the diet with proteins, essential amino acids, vitamins and minerals. Pulses contain protein per cent up to $22-50 \%$, which is almost twice the protein in wheat and thrice that of rice. Among the pulse crops, blackgram (Phaseolus mungo L.) is one of the important pulse crops grown throughout the India, with wider adaptability, suitability under mixed cropping and also has high intensity in crop rotations.
Rapid industrialization and addition of the toxic substances to the environment is responsible for altering the ecosystems, Iqbal and Shafig (2001). Vegetation in the polluted area shows vital decay (Honjyo et al., 1981). The Chemical and physical properties of various particulate (cement, stone crushing and lime kilns) and non-particulate substances act as nutrients at lower concentrations, but at the higher concentration, showed toxic effects on seed germination, dust could produce a number of toxicants which are responsible for the direct or indirect effects on plant seedling growth and adversely affecting plant growth and yield. The cement industry generates a lot 
of dust and plays a vital role in disturbing the environmental equilibrium and produces air pollution hazards (Stern, 1976). The cement, lime dust, and stone crushing are the sources of particulate matter, deposit on the plants and resulting in a significant effect, causes damage to plants by inhibiting many enzyme systems, physiological processes such as photosynthetic ability and respiration rate (Shrinivash and Pandey, 2011), causing visible injury such as reduction in growth and productivity (Subramanian et al., 2011). Cement dust is potentially harmful to the environment.

The direct effects of the cement dust pollution cause alkalization of the ecosystem and changing the chemical composition of the soil can undermine the physico-chemical properties, contaminated soil can adversely affect plant survival and growth (Addo et al., 2013). Stone dust is a primary aerosol and is released directly from the source. Primary aerosol has a detrimental effect on people and environment including changes in flora and fauna, change in soil $\mathrm{pH}$, alters the chemical texture of soil which influences surrounding areas, destruction of habitat, damage of natural resources like valuable vegetation and wildlife, promotion of spreading of many diseases etc. (Das and Nandi, 2002 and Shiva et al., 2006). Keeping the above points in view the study was undertaken to assess the effect of different dust pollutants of various levels on total chlorophyll content, transpiration rate and yield of blackgram.

\section{Materials and Methods}

An experimental study on "Assessment of different dust pollutants effect on total chlorophyll content, transpiration rate and yield of Blackgram (Phaseolus mungo L.)", variety PU-31 was carried out at the Agricultural College Farm, Bapatla, in sandy clay loam soil during kharif 2014-15. The experiment was laid out in randomized block design with ten treatments viz., control -no dust application $\left(\mathrm{T}_{1}\right)$, stone crusher dust @ 50 $\mathrm{gm}^{-2}\left(\mathrm{~T}_{2}\right)$, stone crusher dust @ $100 \mathrm{gm}^{-2}\left(\mathrm{~T}_{3}\right)$, stone crusher dust @ $150 \mathrm{gm}^{-2}\left(\mathrm{~T}_{4}\right)$, lime dust @ $50 \mathrm{gm}^{-2}\left(\mathrm{~T}_{5}\right)$, lime dust @ $100 \mathrm{gm}^{-2}\left(\mathrm{~T}_{6}\right)$, lime dust@150 gm $\mathrm{gm}^{-2}\left(\mathrm{~T}_{7}\right)$, cement dust @ 50 $\mathrm{gm}^{-2}\left(\mathrm{~T}_{8}\right)$, cement dust @ $100 \mathrm{gm}^{-2}\left(\mathrm{~T}_{9}\right)$ and cement dust @150 $\mathrm{gm}^{-2}\left(\mathrm{~T}_{10}\right)$, replicated thrice. Dusting of cement @ $50 \mathrm{gm}^{2}, 100 \mathrm{gm}^{2}$, $150 \mathrm{gm}^{2}$, stone crusher dust @ $50 \mathrm{gm}^{2}, 100$ $\mathrm{gm}^{2}, 150 \mathrm{gm}^{2}$, lime dust @ $50 \mathrm{gm}^{2}, 100 \mathrm{gm}^{2}$, $150 \mathrm{gm}^{2}$ were given at vegetative stage 30 (DAS) as first application and the same concentration was given as a second application at fifteen days thereafter, i.e., at peak flowering stage (45 DAS), besides these, control (without dust) was also maintained. Seeds were treated with the sprint (carbendizem and thirum) and were dibbled at a depth of $5 \mathrm{~cm}$ with a spacing of $30 \times 10 \mathrm{~cm}$. Total chlorophyll content in leaves (SPAD Chlorophyll Meter Readings (SCMR) and transpiration rate $\left(\mathrm{mg} \mathrm{cm}^{-2} \mathrm{hr}^{-1}\right)$ were recorded at specific intervals i.e., at $30 \mathrm{DAS}, 45 \mathrm{DAS}$, 60 DAS and 75DAS. Observations recorded on yield and yield components viz., number of pods per plant, Number of seeds per pod, seed yield $\left(\mathrm{kg} \mathrm{ha}^{-1}\right), 100$ seed weight and harvest index, observations were taken from five randomly selected plants from each plot leaving border rows.

\section{Transpiration rate $\left(\mathrm{mg} \mathrm{cm} \mathrm{cm}^{-2} \mathrm{hr}^{-1}\right)$}

Transpiration rate was measured by using cut leaf method $\left(\mathrm{mg} \mathrm{cm}^{-2} \mathrm{hr}^{-1}\right)$.

Estimation of total chlorophyll content in terms of SPAD Chlorophyll Meter Readings (SCMR)

The total chlorophyll content was measured with SPAD (Soil Plant Analytical Device) Chlorophyll meter readings following the method of Turner and Jund (1991) at 15 days interval after 30 days in each treatment. 


\section{Yield and yield components}

\section{Number of pods per plant}

Mature pods per plant from randomly selected 5 plants per plot were harvested separately and counted.

\section{Number of seeds per pod}

Seeds from each pod were counted and average number of seeds per pod was estimated.

\section{0 seed weight $(g)$}

A small lot of seeds was drawn at random from net plot produce and weighed. Number of seeds constituting sample weight was counted. From these values 100 seed weight (g) was computed.

\section{Harvest index (\%)}

Harvest index was calculated as per Gardner et al., 1985.

\section{Seed yield $\left(\mathrm{kg} \mathrm{ha}^{-1}\right)$}

The pods from each net plot were shelled and seed yield was expressed as $\mathrm{kg} \mathrm{ha}^{-1}$.

\section{Data analysis}

Data analysis was performed by using ANOVA technique by Panse and Sukhatme (1978) for RBD in Microsoft Excel 2010.

\section{Results and Discussion}

Observations were recorded on physiological parameters i.e. total chlorophyll content and transpiration rate at different days after sowing i.e., at 15 days interval starting from $30 \mathrm{DAS}$, 45 DAS, 60 DAS and at harvesting stage. Data on the yield and its components were also recorded at harvest.

\section{Transpiration rate $\left(\mathrm{mg} \mathrm{cm}^{-2} \mathrm{hr}^{-1}\right)$}

Loss of water through stomata from aerial parts of the plant is known as transpiration. The data collected on the effect of stone crusher, lime, cement dust on transpiration rate in blackgram plants were presented in Table 1. Significant differences were observed at all stages of plant growth except for 30 DAS. It increased continuously up to 75 DAS i.e., harvesting stage. At 30 days after sowing transpiration rate was found non-significant in all the treatments due to no dust application. At 45 days after sowing, transpiration rate was significantly decreased in all dust treatments except lime dust @ $50 \mathrm{gm}^{-2}$. Higher decrease in transpiration rate was observed with cement dust @150 gm $\mathrm{gm}^{-2}$ and $100 \mathrm{gm}^{-2}$ (1.799 and $2.043 \mathrm{mg} \mathrm{cm}^{-2} \mathrm{hr}^{-1}$ ) followed by stone crusher and lime dust @150 gm gm $^{-2}$ over control (2.581 $\left.\mathrm{mg} \mathrm{cm}^{-2} \mathrm{hr}^{-1}\right)$. At 60 days after sowing, transpiration rate was significantly decreased in all dust treatments except stone crusher dust and lime dust @ $50 \mathrm{gm}^{-2}$. Higher decrease in transpiration rate was observed with cement dust@150 gm $\mathrm{gm}^{-2}$ and $100 \mathrm{gm}^{-2}$ (1.985 and $2.226 \mathrm{mg} \mathrm{cm}^{-2} \mathrm{hr}^{-1}$ ) followed by stone crusher and lime dust @ $150 \mathrm{gm}^{-2}$ over control (2.816 $\mathrm{mgcm}^{-2} \mathrm{hr}^{-1}$ ). At 75 days after sowing i.e., at harvesting, transpiration rate was significantly decreased in all dust applied treatments. Significant decrease in transpiration rate was observed with cement dust @ 150gm ${ }^{-2}, 100$ $\mathrm{gm}^{-2}$, and $50 \mathrm{gm}^{-2}$, stone crusher dust @ $150 \mathrm{gm}^{-2}, 100 \mathrm{gm}^{-2}$, and $50 \mathrm{gm}^{-2}$ and lime dust @ $150 \mathrm{gm}^{-2}, 100 \mathrm{gm}^{-2}$ and $50 \mathrm{gm}^{-2}$. A higher decrease in transpiration rate was observed with application of cement dust $150 \mathrm{gm}^{-2}$ (2.196 $\mathrm{mgcm}^{-2} \mathrm{hr}^{-1}$ ) over control $(3.193 \mathrm{mg}$ $\left.\mathrm{cm}^{-2} \mathrm{hr}^{-1}\right)$.

Transpiration rate was significantly reduced with cement dust @ $150 \mathrm{gm}^{-2}$ by $1.43,1.42$, and 1.45 folds at 45,60 , and 75 DAS. In the present study, the transpiration rate in all dusted plants was increased with increasing age of the crop. 
Table.1 Effect of stone crusher, lime and cement dust on transpiration rate $\left(\mathrm{mg} \mathrm{cm}^{-2} \mathrm{hr}^{-1}\right)$ of blackgram leaves

\begin{tabular}{|c|c|c|c|c|}
\hline \multirow[t]{2}{*}{ Treatments } & \multicolumn{4}{|c|}{ Transpiration rate $\left(\mathrm{mg} \mathrm{cm}^{-2} \mathrm{~h}^{-1}\right)$} \\
\hline & 30 DAS & 45 DAS & 60 DAS & 75 DAS \\
\hline $\mathrm{T}_{1}$ : Control (No dust application) & 1.753 & 2.581 & 2.816 & 3.193 \\
\hline $\mathrm{T}_{2}:$ Stone crusher dust @ $50 \mathrm{~g} \mathrm{~m}^{-2}$ & 1.589 & 2.332 & 2.623 & 2.846 \\
\hline $\mathrm{T}_{3}:$ Stone crusher dust @ $100 \mathrm{~g} \mathrm{~m}^{-2}$ & 1.648 & 2.253 & 2.480 & 2.673 \\
\hline $\mathrm{T}_{4}:$ Stone crusher dust @ $150 \mathrm{~g} \mathrm{~m}^{-2}$ & 1.705 & 2.091 & 2.333 & 2.465 \\
\hline $\mathrm{T}_{5}:$ Lime dust @ $50 \mathrm{~g} \mathrm{~m}^{-2}$ & 1.714 & 2.479 & 2.724 & 2.921 \\
\hline T6:Lime dust @100 $\mathrm{g} \mathrm{m}^{-2}$ & 1.654 & 2.335 & 2.619 & 2.756 \\
\hline $\mathrm{T}_{7}:$ Lime dust @ $150 \mathrm{~g} \mathrm{~m}^{-2}$ & 1.677 & 2.122 & 2.459 & 2.553 \\
\hline $\mathrm{T}_{8}:$ Cement dust @ $50 \mathrm{~g} \mathrm{~m}^{-2}$ & 1.603 & 2.248 & 2.369 & 2.538 \\
\hline T9: Cement dust @ $100 \mathrm{~g} \mathrm{~m}^{-2}$ & 1.670 & 2.043 & 2.226 & 2.380 \\
\hline $\mathrm{T}_{10}:$ Cement dust @150 $\mathrm{g} \mathrm{m}^{-2}$ & 1.643 & 1.799 & 1.985 & 2.196 \\
\hline $\mathrm{SEm} \pm$ & 0.04 & 0.06 & 0.07 & 0.07 \\
\hline $\mathrm{CD}(\mathrm{P}=0.05)$ & NS & 0.18 & 0.20 & 0.20 \\
\hline $\mathrm{CV}(\%)$ & 4.09 & 4.64 & 4.72 & 4.37 \\
\hline
\end{tabular}

Table.2 Effect of stone crusher, lime and cement dust on total chlorophyll content (SPAD chlorophyll meter readings) of leaves of blackgram

\begin{tabular}{|c|}
\hline Treatments \\
\hline $\mathrm{T}_{1}:$ Control (No dust application) \\
\hline $\mathrm{T}_{2}:$ Stone crusher dust @ $50 \mathrm{~g} \mathrm{~m}^{-2}$ \\
\hline $\mathrm{T}_{3}$ : Stone crusher dust @ $100 \mathrm{~g} \mathrm{~m}^{-2}$ \\
\hline $\mathrm{T}_{4}$ : Stone crusher dust @ $150 \mathrm{~g} \mathrm{~m}^{-2}$ \\
\hline $\mathrm{T}_{5}:$ Lime dust @ $50 \mathrm{~g} \mathrm{~m}^{-2}$ \\
\hline $\mathrm{T}_{6}:$ Lime dust @ $100 \mathrm{~g} \mathrm{~m}^{-2}$ \\
\hline T7: Lime dust @ $150 \mathrm{~g} \mathrm{~m}^{-2}$ \\
\hline $\mathrm{T}_{8}$ : Cement dust @ $50 \mathrm{~g} \mathrm{~m}^{-2}$ \\
\hline T9: Cement dust @ $100 \mathrm{~g} \mathrm{~m}^{-2}$ \\
\hline $\mathrm{T}_{10}:$ Cement dust @ $150 \mathrm{~g} \mathrm{~m}^{-2}$ \\
\hline SEm \pm \\
\hline $\mathrm{CD}(\mathrm{P}=0.05)$ \\
\hline $\mathrm{CV}(\%)$ \\
\hline
\end{tabular}

\begin{tabular}{|c|c|c|}
\hline \multicolumn{3}{|c|}{$\begin{array}{c}\text { Total chlorophyll content (SPAD chlorophyll } \\
\text { meter readings) of leaves }\end{array}$} \\
\hline 30 DAS & 45 DAS & 60 DAS \\
\hline 42.87 & 47.69 & 42.33 \\
\hline 40.45 & 37.94 & 26.99 \\
\hline 39.41 & 34.84 & 24.37 \\
\hline 42.22 & 31.81 & 22.90 \\
\hline 40.96 & 39.41 & 32.75 \\
\hline 41.07 & 37.77 & 30.08 \\
\hline 42.21 & 35.40 & 27.25 \\
\hline 39.66 & 34.57 & 23.46 \\
\hline 38.66 & 32.27 & 22.65 \\
\hline 41.28 & 27.94 & 20.83 \\
\hline $\mathbf{1 . 2 0}$ & $\mathbf{1 . 5 9}$ & $\mathbf{0 . 9 1}$ \\
\hline $\mathbf{3 . 5 7}$ & $\mathbf{4 . 7 3}$ & $\mathbf{2 . 7 1}$ \\
\hline $\mathbf{5 . 1 0}$ & $\mathbf{7 . 6 6}$ & $\mathbf{5 . 7 7}$ \\
\hline
\end{tabular}


Table.3 Effect of stone crusher, lime and cement dust on yield components and yield of blackgram

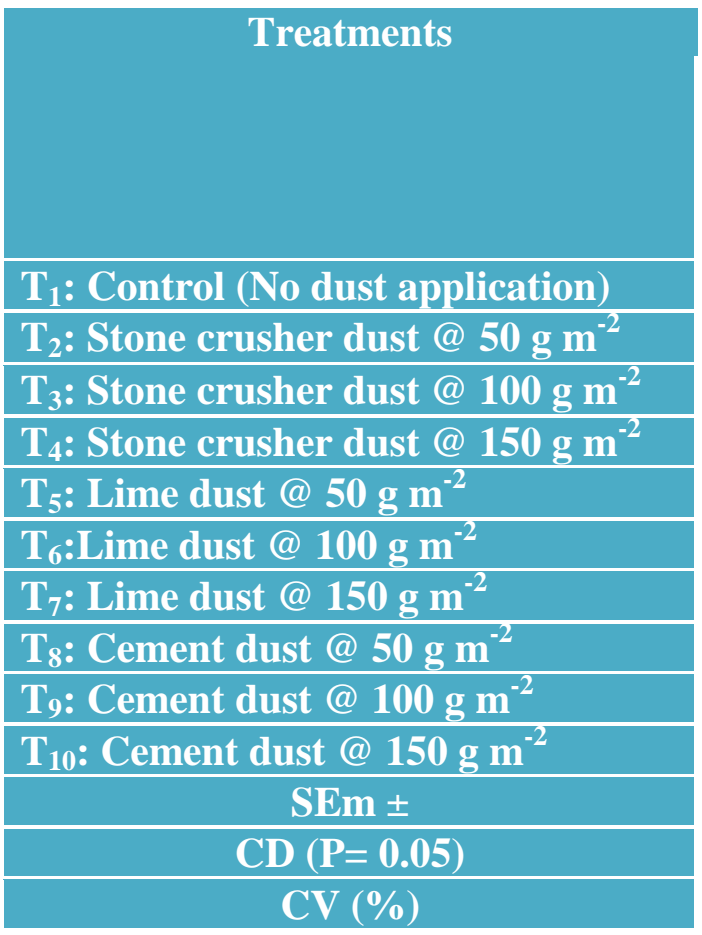

\begin{tabular}{|c|c|c|c|c|}
\hline $\begin{array}{c}\text { Yield components and yield } \\
\text { Total } \\
\text { number } \\
\text { of pods } \\
\text { per plant }\end{array}$ & $\begin{array}{c}\text { Total } \\
\text { number } \\
\text { of seeds } \\
\text { per pod }\end{array}$ & $\begin{array}{c}\text { Harvest } \\
\text { index } \\
(\%)\end{array}$ & $\begin{array}{c}\mathbf{1 0 0} \\
\text { seed } \\
\text { weight } \\
\text { (g) }\end{array}$ & $\begin{array}{c}\text { Seed } \\
\text { yield } \\
\text { (kg/ha) }\end{array}$ \\
\hline 19.43 & 6.00 & 22.8 & 4.55 & 1769 \\
\hline 12.20 & 5.33 & 14 & 4.48 & 971 \\
\hline 11.63 & 5.00 & 12.6 & 4.26 & 826 \\
\hline 10.43 & 4.67 & 10.7 & 4.13 & 670 \\
\hline 16.33 & 5.67 & 19.3 & 4.50 & 1388 \\
\hline 15.07 & 5.33 & 16.7 & 4.37 & 1171 \\
\hline 12.97 & 5.00 & 13.6 & 4.24 & 917 \\
\hline 11.33 & 4.67 & 11.7 & 4.16 & 733 \\
\hline 10.33 & 4.33 & 9.6 & 3.91 & 583 \\
\hline 8.33 & 4.00 & 7.2 & 3.80 & 423 \\
\hline $\mathbf{0 . 4 8}$ & $\mathbf{0 . 3 7}$ & $\mathbf{0 . 9 3}$ & $\mathbf{0 . 0 7}$ & $\mathbf{6 0 . 0}$ \\
\hline $\mathbf{1 . 4 4}$ & $\mathbf{1 . 0 8}$ & $\mathbf{2 . 7 8}$ & $\mathbf{0 . 2 2}$ & $\mathbf{1 7 8 . 3 7}$ \\
\hline $\mathbf{6 . 5 5}$ & $\mathbf{1 2 . 6 5}$ & $\mathbf{1 1 . 7 0}$ & $\mathbf{3 . 0 0}$ & $\mathbf{1 1 . 0 0}$ \\
\hline
\end{tabular}

The plants subjected to high dust showed higher transpiration rate compared to control. This might be due to the thick coating of cement which clog the stomata and prevent the escape of water. Reduced transpiration was also noticed by (Chaurasia et al., 2013) in cement dusted groundnut plants, where, the rate of transpiration increased as the age of plant increased and the distance from industry increased.

\section{Total chlorophyll content (SPAD chrophyll meter readings)}

The data on total chlorophyll content of blackgram plants were presented in Table 2 . Significant differences were observed at all stages of plant growth, with the application of stone crusher dust, lime dust and cement dust. At 30 DAS, the variation observed in total chlorophyll content values was due to variation in sampled plants, among all the treatments cement dust @ $100 \mathrm{gm}^{-2}(38.66)$ showed more decrease in total chlorophyll content over control (42.87) and rest of the treatments were comparable with control. At 45 and 60 days after sowing, total chlorophyll content was significantly decreased in all dust treatments compared to control. The significant decrease in total chlorophyll content was observed with every level (i.e., from $50-150 \mathrm{gm}^{-2}$ ) of cement dust, stone crusher dust, and lime dust. Among all the treatments cement dust @ $150 \mathrm{gm}^{-2}$ showed a higher decrease in total chlorophyll content over control (47.69) at 45 DAS and (42.33) 60 DAS.

Total chlorophyll content was decreased higher with cement dust @ 150 $\mathrm{gm}^{-2}$ by 1.04, 1.71, and 2.03 folds at 30, 45, and 60 DAS, respectively, over control. Similar results were reported by Meerabai et al., (2012) in Cajanus cajan (L.). Exposure to particulate deposition may alter plant growth without physical damage to the plant. Moreover, 
accumulation of dust particulates on plant leaves could be a major problem in their production. It was proposed that the pigments content of the light harvesting complex is an important aspect related to the tolerance of plants to dust pollution. The decrease in chlorophyll content might be due to chloroplast damage by incorporation of cement kiln dust into leaf tissues (Singh and Srivastava, 2002).The similar results were also observed in maize crop by Pandey et al., (1999). The reduction in the concentration of chlorophyll might have also been caused due to the increase in chlorophyllase enzyme activities, which in turn affects the chlorophyll concentration in plants (Mandal and Mukherji, 2000).

\section{Yield and yield components}

At harvest (i.e., 75 DAS), cement dust @ 150 $\mathrm{gm}^{-2}$ recorded lesser number of pods (8.33) and it was on a par with stone crusher dust and lime dust @150 gm ${ }^{-2}$, cement dust, stone crusher dust and lime dust @ $100 \mathrm{gm}^{-2}$, cement dust, stone crusher dust and lime dust @ $50 \mathrm{gm}^{-2}$. At harvesting (i.e., $75 \mathrm{DAS}$ ), total number of pods was reduced more with cement dust @ $150 \mathrm{gm}^{-2}$ by $57.12 \%$. At harvesting (i.e.,75 DAS), cement dust @ $150 \mathrm{gm}^{-2}, 100 \mathrm{gm}^{-2}, 50 \mathrm{gm}^{-2}$ and stone crusher dust @150 gm ${ }^{-2}$ showed significant reduction in total number of seeds per pod (i.e., 4, 4.33, 4.67 and 4.67 respectively) over control (6.0). There was no significant difference in remaining treatments and they were found on a par with control. Reduction in grain yield with deposition of cement dust due to poor pollen germination and fertilization was also reported by Singh and Rao (1980). Moreover, cement dust was also reported to increase the percentage of infertile seeds in sunflower when plants were dusted with cement (Borka, 1980). At harvesting (i.e., 75 DAS), total number of seeds per pod was reduced more with cement dust @ $150 \mathrm{gm}^{-2}$ by $33.33 \%$.
At harvest (i.e., 75 DAS), all treatments showed significant decrease in harvest index compared to control. Lesser harvest index was noticed with cement dust @ $150 \mathrm{gm}^{-2}$ and 100 $\mathrm{gm}^{-2}$ (i.e., 7.2 and 9.6 respectively) over control (22.8). Harvest index was reduced more with cement dust @ $150 \mathrm{gm}^{-2}$ by $68.42 \%$.

At harvest (i.e., 75 DAS), 100 seed weight was significantly decreased with cement dust, stone crusher dust, and lime dust each applied @ $150 \mathrm{gm}^{-2}, 100 \mathrm{gm}^{-2}$ and $50 \mathrm{gm}^{-2}$ over control $(4.55 \mathrm{~g})$. There was no significant difference observed in the remaining treatments. At harvesting (i.e., 75 DAS), 100 seed weight was reduced more with cement dust @ $150 \mathrm{gm}^{-2}$ by $16.48 \%$. At harvest (i.e., 75 DAS), among all the dust applied treatments cement dust and stone crusher dust (a) $150 \mathrm{gm}^{-2}$ showed lesser yield (i.e., 423 and $670 \mathrm{~kg} / \mathrm{ha}$ respectively) over control (1769 $\mathrm{kg} / \mathrm{ha}$ ) and they were found on a par with cement dust @ $50 \mathrm{gm}^{-2}$, stone crusher dust @ $100 \mathrm{gm}^{-2}$ and lime dust @ $150 \mathrm{gm}^{-2}$.The grain yield was reduced more with cement dust @ $150 \mathrm{gm}^{-2}$ by $76.09 \%$ (Table 3 ).

\section{References}

Addo, M.A., Darko, E.O. and Gordon, C. 2013. Contamination of soils and loss of productivity of cowpea (Vigna unguiculata L.) caused by cement dust pollution. International Journal of Research in Chemistry and Environment. 3(1): 272-282.

Borka, G. 1980. The effect of cement dust pollution on growth and metabolism of Helianthus - annus. Environmental Pollution. 22: 75-79.

Chaurasia, S., Karwariya, A. and Gupta, A.D. 2013. Effect of cement industry pollution on chlorophyll content of some crops at Kodinar, Gujarat, India. Proceedings of the International 
Academy of Ecology and Environmental Science. 3(4): 288-295.

Das, D.K. and Nandi, A. 2002. Health hazard in stone quarries and crushers. Science and Technology Project, Government of India, NISM, Kolkata.

Gardner, F.P., Pearce, R.B. and Mitchell, R.L. 1985. Physiology of crop plants. IOWA State University Press, Ames, IOWA.

Honjyo, Takaaki, S., Toshio. and Yuuji, S. 1981. Influence of air pollution on the forest trees. Science Report Kyoto Prefect University of Agricultural science. 32: 125-127.

Iqbal, M.Z. and Shafig, M. 2001. Periodical Effect of Cement Dust Pollution on the Growth of Some Plant Species. Turkish Journal of Botany. 25: 19-24.

Mandal, M. and Mukherji, S. 2000. Changes in chlorophyll content, chlorophyllase activity, hill reaction, photosynthetic $\mathrm{CO}_{2}$ uptake, sugar and starch content in five dicotyledonous plants exposed to automobile exhaust pollution. Journal of Environmental Biology. 20: 37-41.

Meerabai, G., Venkata Ramana, C. and Rasheed, M.2012. Effect of industrial pollutants on physiology of Cajanus cajan (L.)-Fabaceae. International Journal of Environmental Sciences. 2(4): 1889-1894.

Pandey, D.D., Nirala, A.K. and Gaulam, R.R. 1999. Impact of stone crusher dust pollution on maize crop. Indian Journal of Environment and Ecoplanning. 2: $43-$ 46.

Panse, M. and Sukhatme, K. 1978. Statistical Methods for Agriculture Workers. ICAR, New Delhi. 37(1): 59-67.
Shiva Coumar, R., Jayabalou, R., Swarnalatha, S. and Balakrishnan, K. 2006. Particulate matter from stone crushing industry: Size distribution and health effects Journal of Environmental Engineering-ASCF. 132(3): 405.

Shrinivash, M. and Pandey, R.P. 2011. Effect of urban area dust pollution on the growth of some plant species. VSRD Technical and Non-Technical Journal. 2(9): 442-448.

Singh, R.B. and Shrivastava, A.K. 2002. Cytotoxic effects and biological damages in Clitoriaternatie by cement dust. National Environmental Pollution Research. 1: 457-461.

Singh, S.N. and Rao, D.N. 1980. Growth responses of wheat plants to cement dust polluted environment. Proceedings of Indian National Science Academy. 46: 325:329.

Stern, A.C. 1976. Air pollution, measurement, monitoring and surveillance of air pollution. $3^{\text {rd }}$ ed., Academic Press, New York.

Subramanian, R.D., Sundaramoorthy, P., Baskaran, L., Sankar Ganesh, K., Chidambaram, A.L.A. and Jeganathan, M. 2011. Effect of cement dust pollution on germination and growth of groundnut (Arachis hypogaea L.) International Multidisciplinary Research Journal. 1(1): 25-30.

Turner, F.T. and Jund, M.F. 1991. Chlorophyll meter to predict nitrogen top dress requirement for semi dwarf rice. Agronomy Journal. 83: 926-928.

\section{How to cite this article:}

Hareesh Babu, P., K.L. Narasimha Rao, K. Jayalalitha and Mohammed Anwar Ali. 2018. Assessment of Different Dust Pollutants Effect on Total Chlorophyll Content, Transpiration Rate and Yield of Blackgram (Phaseolus mungo L.). Int.J.Curr.Microbiol.App.Sci. 7(04): 2890-2896. doi: https://doi.org/10.20546/ijcmas.2018.704.329 